\title{
Effect of salting method on salt concentration in Dhaka cheese
}

\section{R Habib*}

Department of Dairy Science, Bangladesh Agricultural University, Mymensingh 2202, Bangladesh

\begin{abstract}
This research was conducted to study the effect of salting method on salt concentration in Dhaka cheese. Dhaka cheese was made in the laboratory on pilot scale and salted either by dry salting, or salt stuffing, or brining, or their combinations. Two levels of dry salting was applied, $1 \%$ and $2 \%$, w/w. The use of different salting method had a significant $(P<0.001$ to 0.05$)$ influence on salt concentration, and distribution of salt between rind and core. Brined cheeses appeared attain a quick salt equilibrium as compared to other methods. Increasing salt content from 1 to $2 \%(\mathrm{w} / \mathrm{w})$ increased the salt concentration $(P<0.001)$. Combination of $2 \%$ (w/w) salt stuffing and brining showed significantly better $(P<0.001)$ distribution of salt followed by only brining.
\end{abstract}

Key words: Dhaka cheese, method, salting level, concentration

\section{Introduction}

Salting is an important step in cheese making because unsalted cheese is virtually tasteless (Olson, 1995). Salt $(\mathrm{NaCl})$ contributes directly to cheese flavour. It fulfils many other important functions in cheese like ripening, and physicochemical and functional characteristics of cheese. Excessive proteolysis, bitterness, other off-flavors, and low $\mathrm{pH}$ are frequently associated with low salt, while high salt retarded maturation and influences texture. So, the concentration of salt in cheese is considered to be one of the most important factors influencing the quality of cheese (Turner and Thomas, 1980; Lawrence and Gilles, 1982; Lindsay et al., 1982; Kindstedt et al., 1992; Guo et al., 1997; Paulson et al., 1998). Salt concentration in cheese may range from less than $1 \%$ to $8 \%$, w/w, depending on the cheese variety (Fox and McSweeney, 1998).

Method of salting, time of salting, and amount of salt differ, depending upon the variety and manufacturer. Salt is most commonly added to the whey-free curd either prior to putting the curd into the mould or after the pressed block of cheese has been removed from the mould. Salt may be applied by sprinkling dry salt on cheese surface, or by immersing the cheese in brine (Johnson and Law, 1999). The brine is usually a saturated salt solution ( $\mathrm{ca}$. 23\%, w/w). Cheddar and its variants are salted by mixing dry salt with milled curd. However, in many cheese varieties the surface salting and brining are combined. Miah and Quddus (1970) applied a different method of dry salting for Dhaka cheese, which was accomplished by stuffing salt through 2-3 centrally bored holes extending from the surface to the core.

Dhaka cheese is a white, semi-hard artisanal cheese that has been manufactured traditionally in Bangladesh. This variety is made from bovine milk or from a mixture of cow and buffalo milks. Dhaka cheese is ripened for minimum one week. This variety has a characteristic hard, crumbly texture and a strong, salty flavour. Common salt $(\mathrm{NaC} 1)$ is an important constituent of Dhaka cheese for its role in preservation and organoleptic quality. Miah and Quddus (1970) reported 4.30 to $5.12 \%$, w/w, salt in the commercial Dhaka cheese. 
Although there is a number of works regarding method of salting on the salt concentration in cheddar cheese (Moms, 1961; Lawrence and Gilles, 1969; O'Connor, 1974; Guinne and Fox, 1987) and Feta cheese (Pappas et al., 1996), there is little information concerning Dhaka cheese (Miah and Quddus, 1971). Relatively few studies have directly focused upon the impact of salting method on the salt concentration of cheese. One of the salting methods dry salting -is not practiced for commercial cheeses. This study, therefore, investigated the effects of different salting methods and duration of the process on the final salt content of Dhaka cheese.

\section{Materials and Methods}

\section{Cheese making and salting process}

Whole cow milk was collected from the market and a mixed mesophilic starter culture (DVS, Chr. Hansen's Laboratories Ltd.) was added. After $30 \mathrm{~min}$ a quantity (16.0 g) of rennet (CHY-MAX Plus, Chr. Hansen's Laboratories Ltd.) was added to coagulate the milk in 50-55 min at $32^{\circ} \mathrm{C}$. The curd was cut into 2-2.5 cm pieces and drained in muslin cloth for 2 hours. The drained curd was kneaded for $1 \min (\sim 2$ $\mathrm{kg}$ at a time). Part of the curd was separated and divided into two portions, and common salt ( 1 \& $2 \%$, $\mathrm{w} / \mathrm{w}$, respectively) was mixed manually for 30 seconds prior to filling into moulds, $800 \mathrm{~g}$ in each mould (mould $1 \& 2$ ). The unsalted curd was then transferred into 5 different moulds (800 g per mould). Two of the moulds (moulds $3 \& 5$ ) were salted with common salt $(1 \%$, w/w) by stuffed onto three separate locations into centrallty bored holes. Two other moulds (moulds $4 \& 6$ ) were stuffed with $2 \%$, w/w, salt at similar locations. The remaining mould (mould 7) was salted by brining after pressing. A follower was placed on the top of each curd mass prior to pressing. Pressing was accomplished at 15.6 $\mathrm{kPa}$ cheese surface pressure by a pneumatic press for 12 hours. After the cheeses were taken out of the moulds, the unsalted cheese from the $7^{\text {th }}$ mould was transferred in a tub of $10 \mathrm{~kg}$ saturated brine solution $\left(\approx 23 \%\right.$, w/w, at $\left.24^{\circ} \mathrm{C}\right)$, while the other six salted cheeses were put on a tray. At the end of $3^{\text {rd }}$ day, cheeses from moulds $5 \& 6$ from batches $2 \& 3$ were transferred to a saturated brine solution. Salted loaves were turned upside down twice a day for proper salt distribution.

\section{Analyses of salt concentration}

Cheeses were analysed for salt concentration on $2^{\text {nd }}$, $5^{\text {th }}$ and $8^{\text {th }}$ days of salting. The cheese loaves were removed from the shelf/ brine container wiped with paper towel. Then a portion of about $150 \mathrm{~g}$ was cut from each block so that it contains all portions from the centre to the surface. The same sampling regions were used on all occasions. Each slice was sealed in an airtight pack and stored in the refrigerator at $2^{\circ} \mathrm{C}$ until analysis. Milk and cheese were sampled according to standard methods (AOAC, 2005) and analysed in duplicate. The salt content in cheese and brine was measured by a TitraLab TIM 840 Titration Workstation (Radiometer Analytical SAS, France) from 1-g samples.

\section{Statistical analysis}

The results were analysed for descriptive statistics including mean and standard deviation (SD) followed by analysis of variance (ANOVA) using the SPSS version 17.0 (IBM). The effects (interactions) of salting method, duration of salting and location of samples (core and rind) on salt concentration of each block of Dhaka cheese were studied with a $7 \times 3 \times 2$ factorial test in a randomised block design where day of salting and section of cheese were considered a covariate (Steel et al., 1996). The variables for the factorial experiment were:

a) Salting method 1, 2, 3, 4, 5, 6 \& 7,

b) Duration of salting: $+1,+4$ and $+7 \mathrm{~d}$; and,

c) Section of cheese: core (inner $50 \%$ of the cheese block) and rind (outer $50 \%$ of the cheese block).

Data of each sampling day were also analysed statistically by one way ANOVA. Means with a significant difference $(\mathrm{P}<0.05)$ were compared by the Duncan's New Multiple Range test. The data were also subjected to ANOVA to find out significant differences between days $(+1,+4 \&+7)$ for each salting method, followed by the Duncan's New Multiple Range test. The experiment was carried out in duplicate. 


\section{Results and Discussion}

Salting method influenced salt absorption and distribution. Thus, the salt content of cheeses significantly increased $(P<0.001$ to 0.05$)$ both in the core and rind during the one week observation period. There was also a good correlation as a function of time. The highest salt content was observed with method 7, followed by method 6 . There were significant effects of interactions among salting method, section of cheese and duration of salting (Table 3). The rate of increase became slow after fourth day, except for brined cheeses. Increasing the level of $\mathrm{NaCl}$ from $1 \%, \mathrm{w} / \mathrm{w}$, to $2 \%$, $\mathrm{w} / \mathrm{w}$, significantly $(P<0.001)$ increased the salt content of cheeses (methods 2, 4 \& 6). The differences in salt concentrations in cheese made by salt stuffing and dry salting were small in magnitude. In general, salt absorption was higher in the brined samples (methods 5 to 7) than in the dry salted or salt stuffed samples.

Results in Tables $1 \& 2$ show that $\mathrm{NaCl}$ equilibrium did not establish throughout the loaves even after seven days. Salt contents of the cheeses from methods 2, 4, 5, 6 \& 7 attained the desired salt concentration at day +4 or onward, though the other two methods ( $1 \& 3$ ) resulted in concentrations less than required. Miah and Quddus (1970) reported a range of 4.30-5.12\%, w/w, salt in commercial Dhaka cheese. However, in a later study they observed salt content from 2.16 to $2.45 \%$, $\mathrm{w} / \mathrm{w}$, in various treatments on the $3^{\text {rd }}$ day (Miah and Quddus, 1971). Higher salt absorption in the brined samples than in the dry salted or salt stuffed samples could be attributed to the fact that more salt was available to penetrate the cheese block from the brine. When cheese is placed in brine, there is a net movement of $\mathrm{NaCl}$ into the cheese and cheese moisture into the brine (Fox, 1987; Turhan and Kaletunc, 1992). Geurts et al. (1974) concluded that the penetration of salt into cheese and the simultaneous outward migration of water in brine-salted Gouda-type cheeses could be described as an impeded diffusion process.

Table 1. Salt content (mean percentage, $w / w$ ) in core of Dhaka cheese made with different methods of salting ${ }^{1}$.

\begin{tabular}{|c|c|c|c|c|}
\hline \multirow[t]{2}{*}{ Method of Salting } & \multicolumn{4}{|c|}{$\%, \mathrm{w} / \mathrm{w}$, Salt in core } \\
\hline & Day $+1 * * *$ & Day $+4^{* * *}$ & Day $+7 * * *$ & $\mathrm{R}^{2}$ \\
\hline Method $1(1 \%$, w/w, Dry Salting)*** & $0.91^{\mathrm{d} 3} \pm 0.01$ & $1.14^{\mathrm{d} 2} \pm 0.02$ & $1.26^{\mathrm{d} 1} \pm 0.04$ & 0.95 \\
\hline Method 2 (2\%, w/w, Dry Salting)*** & $2.05^{\mathrm{a} 2} \pm 0.03$ & $1.94^{\mathrm{C} 3} \pm 0.03$ & $2.24^{\mathrm{C} 1} \pm 0.03$ & 0.37 \\
\hline Method 3 (1\%, w/w, Salt Stuffing)*** & $1.06^{\mathrm{b} 3} \pm 0.01$ & $1.14^{\mathrm{d} 2} \pm 0.03$ & $1.20^{\mathrm{d} 1} \pm 0.03$ & 0.88 \\
\hline Method 4 (2\%, w/w, Salt Stuffing)*** & $1.64^{\mathrm{a} 3} \pm 0.02$ & $2.13^{\mathrm{b} 2} \pm 0.03$ & $2.20^{\mathrm{c} 1} \pm 0.02$ & 0.84 \\
\hline $\begin{array}{l}\text { Method } 5(1 \% \text {, w/w, Salt Stuffing plus } \\
\text { brining)*** }\end{array}$ & $1.02^{\mathrm{c} 2} \pm 0.04$ & $1.07^{\mathrm{e} 2} \pm 0.04$ & $2.18^{\mathrm{c} 1} \pm 0.05$ & 0.78 \\
\hline $\begin{array}{l}\text { Method } 6(2 \% \text {, w/w, Salt Stuffing plus } \\
\text { brining)*** }\end{array}$ & $1.64^{\mathrm{a} 3} \pm 0.03$ & $2.11^{\mathrm{b} 2} \pm 0.02$ & $3.67^{\mathrm{b} 1} \pm 0.08$ & 0.91 \\
\hline Method 7 (Brining)*** & $0.85^{\mathrm{e} 3} \pm 0.03$ & $2.33^{\mathrm{a} 2} \pm 0.03$ & $4.70^{\mathrm{a} 1} \pm 0.15$ & 0.98 \\
\hline
\end{tabular}

${ }^{1}$ Mean values \pm SD for 2 replicates of each type of cheese, analysed in duplicate $(n=4)$.

a,b,c Means within the same column without a common superscript are significantly different: $* * * P<0.001$

${ }^{1,2,3}$ Means within the same row without a common superscript are significantly different: ${ }^{* * *} P<0.001$

The increase occurred throughout the 1 week of salting which was also observed by Prasad and Alvarez (1999) in Feta cheese. These observations are similar to the results reported by Guinee and Fox (1985) for Romano cheese, and Robinson and Tamime (1996) for Feta cheese. Salt diffusion during brine salting of cheese has been extensively studied by many researchers (Geurts et al., 1974, 1980; Guinee and Fox, 1983, 2004). Depending on cheese variety and other factors the diffusion coefficient of $\sim 0.12 \mathrm{~cm}^{2} / \mathrm{d}$ has been established for $\mathrm{NaC} 1$ in cheese moisture. It has also been reported 
that salt equilibrium is approached within 30 to 50 days, depending on the moisture content of the cheese (Guinee and Fox, 1983).

Although the traditional method of manufacturing Dhaka cheese is simple, considerable variations exist among the processing conditions and procedures. A basic description of Dhaka cheese production at artisanal scale has been presented by Miah and Quddus (1970). A high salt content is a characteristic feature of Dhaka cheese. In the current study, we found a wide variation $(P<0.001)$ between rind and core of the cheese. Miah and Quddus (1970) reported a lack of uniformity in salt distribution throughout the block, which supports the findings of this research. A wide variation in $\mathrm{NaCl}$ concentration as a function of the distance from the cheese-brine

Table 2. Salt content (mean percentage, w/w) in rind of Dhaka cheese made with different methods of salting ${ }^{1}$

\begin{tabular}{|c|c|c|c|c|}
\hline \multirow[t]{2}{*}{ Method of Salting } & \multicolumn{4}{|c|}{$\%, \mathrm{w} / \mathrm{w}$, Salt in rind } \\
\hline & Day $+1 * * *$ & Day $+4 * * *$ & Day $+7 * * *$ & $\mathrm{R}^{2}$ \\
\hline Method 1 (1\%, w/w, Dry Salting)*** & $1.04^{\mathrm{c} 2} \pm 0.05$ & $1.15^{\mathrm{f} 1} \pm 0.02$ & $1.16^{\mathrm{f} 1} \pm 0.01$ & 0.68 \\
\hline Method 2 (2\%, w/w, Dry Salting)* & $2.13^{\mathrm{a} 2} \pm 0.04$ & $2.17^{\mathrm{c} 12} \pm 0.02$ & $2.19^{\mathrm{e} 1} \pm 0.02$ & 0.54 \\
\hline Method 3 (1\%, w/w, Salt Stuffing)*** & $1.01^{\mathrm{c} 2} \pm 0.01$ & $1.06^{\mathrm{g} 1} \pm 0.02$ & $1.08^{\mathrm{f} 1} \pm 0.02$ & 0.73 \\
\hline Method 4 (2\%, w/w, Salt Stuffing)*** & $1.78^{\mathrm{b} 3} \pm 0.05$ & $2.09^{\mathrm{d} 2} \pm 0.06$ & $2.31^{\mathrm{d} 1} \pm 0.01$ & 0.96 \\
\hline $\begin{array}{l}\text { Method } 5(1 \%, w / w, \text { Salt Stuffing plus } \\
\text { brining)*** }\end{array}$ & $1.06^{\mathrm{c} 3} \pm 0.02$ & $1.76^{\mathrm{e} 2} \pm 0.03$ & $3.66^{\mathrm{c} 1} \pm 0.06$ & 0.93 \\
\hline $\begin{array}{l}\text { Method } 6(2 \%, w / w \text {, Salt Stuffing plus } \\
\text { brining)*** }\end{array}$ & $1.81^{\mathrm{b3}} \pm 0.05$ & $2.43^{\mathrm{b} 2} \pm 0.08$ & $5.16^{\mathrm{b} 1} \pm 0.08$ & 0.56 \\
\hline Method 7 (Brining)*** & $1.75^{\mathrm{b} 3} \pm 0.01$ & $4.49^{\mathrm{a} 2} \pm 0.06$ & $7.19^{\mathrm{a} 1} \pm 0.15$ & 0.99 \\
\hline
\end{tabular}

${ }^{1}$ Mean values \pm SD for 2 replicates of each type of cheese, analysed in duplicate $(n=4)$.

a,b,c Means within the same column without a common superscript are significantly different: ${ }^{* * *} P<0.001$.

${ }^{1,2,3}$ Means within the same row without a common superscript are significantly different: $* * * P<0.001$; ${ }^{*} P<$ 0.05 .

Table 3. Probability from ANOVA of the interaction effects of different salting methods on salt concentration of Dhaka cheese ${ }^{1}$

\begin{tabular}{|l|c|c|c|c|}
\hline Parameter & Method $^{2} \times$ Day $^{3}$ & Method $^{2} \times$ Section $^{4}$ & Day $^{3} \times$ Section $^{4}$ & $\begin{array}{c}\text { Method }^{2} \times \text { Day }^{3} \times \\
\text { Section }^{4}\end{array}$ \\
\hline Salt & $* * *$ & $*$ & $* * *$ & $* * *$ \\
\hline
\end{tabular}

${ }^{1}$ Results are derived from $F$ tests (type III Sum of Square).

${ }^{2}$ Method: 1, 2, 3, 4, 5, 6 \& 7.

${ }^{3}$ Day : $+1,+4 \&+7$.

${ }^{4}$ Section : Core $\&$ Rind.

$* * *=P<0.001$; and $*=P<0.05$.

interface was observed by Guinee and Fox (1985) in brine-salted cheese. It was also evident that brining after salt stuffing (methods 5 \& 6) caused a remarkable increase in the salt absorption due to higher salt availability, as mentioned earlier. The increase was rather small, though significant, just after one day of transfer to the brine, which might be due to the thin rind formed that barred salt penetration. However, on the following days this rind was softened by the moisture and salt penetrated freely. There was a clear evidence of mould growth on cheeses salted by methods 1, 2, 3 \& 4. However, 
no mould growth was visible in brined cheeses. This suggested that cheeses with higher salt levels in the rind had more protection against mould growth than cheeses containing less salt. Moreover, higher salt concentration should be desirable in Dhaka cheese due to its role in increasing the osmotic pressure of the aqueous phase to cause dehydration and inactivation of bacterial cells. Thereby, salt acts as a critical hurdle to control growth of spoilage organisms in this variety during its ripening in the higher ambient temperature $\left(\sim 24^{\circ} \mathrm{C}\right)$ typical in Bangladesh. However, too high a concentration could impart undesirable flavour and texture and reduce consumer acceptance. In the current study the steady decline in $\mathrm{pH}$ indicated that some starter organisms were still viable and produced acid despite increased salt concentration.

\section{Conclusion}

This study showed that salt distribution may also be very uneven within the cheese loaf as influenced by the salting method. The time required to complete the salting procedure, i.e. attain at least $2 \%$, w/w, salt, for brined and stuffed plus brined cheeses was three days less than that required for the dry salted cheese. The results also revealed that brine salting should not be carried on beyond at four days to prevent salt content from rising above the targeted concentrations $(2-5 \%, \mathrm{w} / \mathrm{w})$. This experiment indicated that although establishment of salt equilibrium in Dhaka cheese was fast, one week was not sufficient. In conclusion, $2 \%$ salt boring plus brining (method 6 ) was found to be the best method for salting Dhaka cheese, followed by brining (method 7).

\section{References}

AOAC (2005). Dairy Products, in Official Methods of Analysis, $18^{\text {th }}$ edition, chapter $33, \mathrm{~W}$ Horwitz editor, pp. 1-4, 72-73. AOAC International, Gaithersburg, USA.

Fox PF (1987). Significance of salt in cheese ripening. Dairy Industries International, 52(9): 19-22.

Fox PF, McSweeney PLH (1998). Dairy chemistry and biochemistry. Blackie Academic \& Professional, London, UK.
Geurts TJ, Walstra P, Mulder H (1974). Transport of salt and water during salting of cheese. 1 . Analysis of the processes involved. Netherlands Milk and Dairy Journal. 28: 102129.

Geurts TJ, Walstra P, Mulder H (1980). Transport of salt and water during salting of cheese. 2. Quantities of salt taken up and of moisture lost. Netherlands Milk and Dairy Journal. 34: 229-254.

Guinee TP, Fox PF (1983). Sodium chloride and moisture changes in Romano-type cheese during salting. Journal of Dairy Research. 50: 511-518.

Guinee TP, Fox PF (1985). Transport of sodium chloride and water in Romano cheese slices during brining. Food Chemistry. 19: 49-64.

Guinee TP, Fox PF (1993). Salt in cheese: physical, chemical and biological aspects, in Cheese: Chemistry, Physics and Microbiology, General Aspects, 2nd edition. volume 1, PF Fox editor, pp. 257-302. Chapman \& Hall, London, UK.

Guinee TP, Fox PF (2004). Salt in cheese: physical, chemical and biological aspects, in Cheese: Chemistry, Physics and Microbiology, General Aspects, 3rd edition, volume 1, PF Fox, PLH McSweeney, TM Cogan and TP Guinee editors, pp. 207-259. Elsevier Ltd, London, UK.

Gunasekaran S, Ak MM (2003). Cheese Rheology and Texture. CRC Press LLC., Florida, USA.

Guo MR, Gilmore JA, Kindstedt PS (1997). Effect of sodium chloride on the serum phase of mozzarella cheese. Journal of Dairy Science. 80: 3092-3098.

Johnson M, Law BA (1999). The origins, development and basic operations of cheesemaking technology in Technology of cheesemaking, B. A. Law Editor, pp.1-32. Sheffield Academic Press, Sheffield, UK.

Kindstedt PS, Kieley LJ, Gilmore JA (1992). Variation in composition and functional properties within brine salted Mozzarella cheese. Journal of Dairy Science. 75: 29132921. 
Lawrence RC, Gilles J (1982). Factors that determine the $\mathrm{pH}$ of young Cheddar cheese. New Zealand Journal of Dairy Science and Technology. 17: 1-14.

Lindsay RC, Hargett SM, Bush CS (1982). Effect of sodium/potassium (1:1) chloride and low sodium chloride concentrations on quality of Cheddar cheese. Journal of Dairy Science. 65: 360-370.

Miah AH, Quddus A (1970). Standards and standardization in the manufacture of Dacca cheese - I. A. Standards of commercial Dacca cheese. Bangladesh Journal of Animal Science. 3(1-2): 33-38.

Miah AH, Quddus A (1971). Standards and standardization in the manufacture of Dacca cheese - II. B. Effect of manufacturing. Bangladesh Journal of Animal Science. 4(12): 23-31.

Moms TA (1961). Observations on the salting of Cheddar and Gouda cheese. Australian Journal of Dairy Technology. 16: 31.

O’Connor CB (1974). The quality and composition of Cheddar cheese: effect of various rates of salt addition. Part III. Irish Agricultural and Creamery Review. 27: 11-13.

Olson NF (1995). Cheese, in Biotechnology, volume 9, HJ Rehm and G Reed editors, pp. 355-384, Verlag Chemie, Wenheim, Germany.

Pappas CP, Kondyli E, Voutsinas LP, Mallatou H (1996). Effects of salting method and storage time on composition and quality of Feta cheese. Journal of Society of Dairy Technology. 49: 113-118.

Paulson BM, McMahon DJ, Oberg CJ (1998). Influence of sodium chloride on appearance, functionality, and protein arrangements in non-fat Mozzarella cheese. Journal of Dairy Science. 81: 2053-2064.

Prasad N, Alvarez VB (1999). Effect of salt and chymosin on the physicochemical properties of Feta cheese during ripening. Journal of Dairy Science. 82: 1061-1067.

Robinson RK, Tamime AY (1996). Traditional Feta cheese and manufacture of Feta cheese industrial, in Feta and Related Cheeses. London: Woodhead Publishing Ltd., pp. 49136.

Steel RGD, Torrie JH (1996). Principles and procedures of statistics: a biometric approach, $3^{\text {rd }}$ edition, DA Dickey editor, McGraw-Hill Inc., New York, USA.

Turhan M, Kaletunç G (1992). Modelling of salt diffusion in white cheese during long-term brining. Journal of Food Science. 57: 10821085.

Turner KW, Thomas DT (1980). Lactose fermentation in Cheddar cheese and effect of salt. New Zealand Journal of Dairy Science and Technology. 15: 265-276. 